\title{
Plumeria Alba Latex as a New Plant Protease for Waragashi Cheese Production: A Comparative Assessment of Yield and Physicochemical and Textural Characteristics
}

\author{
Bankolé Ibidjokè Rachidatou ${ }^{1}$, Tchobo Fidèle Paul ${ }^{1, ~ *}$, Mazou Mouaïmine ${ }^{1}$, \\ Hodonou Myriam Mondoukpè ${ }^{1}$, Durand Erwann ${ }^{2}$, Alitonou Guy Alain ${ }^{3}$ \\ ${ }^{1}$ Unit of Research in Enzymatic and Food Engineering, University of Abomey-Calavi, Cotonou, Benin \\ ${ }^{2}$ Centre de Coopération Internationale en Recherche Agronomique Pour le Développement, Campus Supagro/INRA, Montpellier, France \\ ${ }^{3}$ Recherch Unit of Plant Extracts and Natural Flavors, University of Abomey-Calavi, Cotonou, Benin
}

Email address:

fideletchobo@gmail.com (T. F. Paul), fidele.tchobo@epac.uac.bj (T. F. Paul)

${ }^{*}$ Corresponding author

\section{To cite this article:}

Bankolé Ibidjokè Rachidatou, Tchobo Fidèle Paul, Mazou Mouaïmine, Hodonou Myriam Mondoukpè, Durand Erwann, Alitonou Guy Alain. Plumeria Alba Latex as a New Plant Protease for Waragashi Cheese Production: A Comparative Assessment of Yield and Physicochemical and Textural Characteristics. Journal of Food and Nutrition Sciences. Vol. 7, No. 5, 2019, pp. 73-78. doi: 10.11648/j.jfns.20190705.13

Received: August 5, 2019; Accepted: September 6, 2019; Published: October 23, 2019

\begin{abstract}
The Peuhl cheese (Waragashi, Warangachi, Wagashi, or Wara in local language) is a soft cheese with a high nutritional value, prepared by coagulation of whole milk under the action of calotropaïne, a plant enzyme from Calotropis procera. In this study, Plumeria alba latex has been used as an alternative source of enzymes for the production of Waragashi cheese. The effect of temperature on the milk-clotting activity (MCA), as well as the physicochemical properties of the Waragashi cheeses were investigated and compared with the ones prepared with $C$. procera and $C$. papaya latices. C. procera and C. papaya latices exhibited a maximum MCA at temperatures close to $55^{\circ} \mathrm{C}$, while $P$. alba latex exhibited a maximum MCA at temperatures close to $80^{\circ} \mathrm{C}$. Waragashi cheese produced using $P$. alba showed textural properties comparable with those prepared using C. procera, while the yield of production varied as a function of the quantity of the different coagulants and milk temperature. The results of these studies, it is clear that the $P$. alba latex can be used to produce Waragashi cheese, similar to the latices of $C$. procera and $C$. papaya. the next challenge of this study is to verify the toxicity of $P$. Alba latex.
\end{abstract}

Keywords: Waragashi Cheese, Plant Proteases, Milk-clotting Activity

\section{Introduction}

The Peuhl cheese (Waragashi, Warangachi, Wagashi, or Wara in local language) is a soft cheese with a high nutritional value, prepared by coagulation of whole milk under the action of calotropaïne, a plant enzyme from Calotropis procera. All parts of C. procera (leaves, stems, fruits, and latex) have been reported to exhibit coagulant activity on milk casein [1]; therefore, the entire plant is used for manufacturing cheese. However, the leaves and stems give approximately the same results, and the fruits are less effective, while the latex presents the greatest activity [1]. Despite being popular for its therapeutic properties, the predation on the C. procera plant causes its depletion and gradual disappearance. In addition, the genetic erosion of the species will be detrimental to biodiversity, and especially to the survival of Peuhl communities. Nevertheless, the use of vegetable extracts as milk coagulants in soft cheese processing has been known since antiquity [2]. Milk coagulants of plant origin have been preferred over animal rennet, the use of which has been limited due to religious reasons, diet, or safety risks posed by genetically engineered foods [3]. In addition, experiments have demonstrated a better production of cheese with vegetable coagulants [2], as observed in the early maturation of Camembert cheese prepared with Cynara sp. (cardoon) extract in comparison 
with animal rennet [3]. Plumeria alba is an interesting alternative because the properties of its latex are similar to that of C. procera.

The genus Plumeria, a shrub native to South America, is cultivated throughout the world as an ornamental plant [4] From the West Indian islands, the genus Plumeria for the apocynaceae family is now widespread throughout the tropics. The stems of this genus are very thick and fleshy that bald during flowering, and have at their end bouquets of red, pink, yellow, orange or white flowers, depending on the species. For example, the flowers of P. alba are red, whereas those of P. rubra are white. The flowers of Plumeria sp. are used in foods (pastries and jams), in cosmetics and ornaments, or for the disinfectant properties of the essential oil extracted therefrom [4]. Its thick branches contain a milky latex that may be used to burn warts. Herein, the aim of this study was to use P. alba as a coagulant to substitute $C$. procera, for the production of Waragashi cheese. Moreover, a comparative assessment of the yields, physicochemical, and textural characteristics of cheese prepared with the latices of P. alba, C. procera, and C. papaya was performed.

\section{Materials and Methods}

\subsection{Samples and Chemicals}

The samples regroup essentially the milk, the latex of Calotopis procera, the latex of Carica papaya and the latex of Plumeria alba. The milk used for Waragashi preparation was obtained from a Peulh camp at Abomey-Calavi. The latex of Calotopis procera, of Carica papaya and Plumeria alba were taken at Abomey-Calavi campus and were used to clotting the milk. All chemical products were purchased from Sigma (Saint Quentin, France).

\subsection{Experimental Design}

For the optimization of efficacy of different coagulant into the production of waragashi, the experiments were conducted according to a central composite design with two variables. The central composite design predicts uniformly at all constant distances from the center points. The design was generated by Design Expert statistical software (version 6.0, Stat-Ease, Inc., Minneapolis, $\mathrm{MN})$, (Table 1). The variables were process temperature $\left(40^{\circ} \mathrm{C}-70^{\circ} \mathrm{C}\right)$ and coagulant quantity $(5 \mathrm{~mL}-25 \mathrm{~mL})$.

Table 1. Experimental design of process variables of experimental data for the yield of the production of waragashi.

\begin{tabular}{llll}
\hline Coded process variables & \multicolumn{2}{l}{ Uncoded process variables } \\
\hline $\begin{array}{l}\text { Milk temperature } \\
\left(\mathbf{x}_{\mathbf{1}}\right)\end{array}$ & $\begin{array}{l}\text { Coagulant } \\
\text { quantity }\left(\mathbf{x}_{\mathbf{2}}\right)\end{array}$ & $\begin{array}{l}\text { Milk temperature } \\
(\mathbf{X} 1)^{\circ} \mathbf{C}\end{array}$ & $\begin{array}{l}\text { Coagulant } \\
\text { quantity }\left(\mathbf{X}_{2}\right) \mathbf{~} \mathbf{L} \mathbf{L}\end{array}$ \\
\hline 1 & 1 & 25 & 40 \\
-1 & 1 & 15 & 70 \\
0 & 1 & 15 & 55 \\
1 & 1 & 25 & 70 \\
1 & 1 & 5 & 70 \\
0 & 1 & 15 & 55 \\
1 & 1 & 5 & 40 \\
0 & 1 & 15 & 55 \\
\hline
\end{tabular}

\begin{tabular}{llll}
\hline \multicolumn{2}{l}{ Coded process variables } & \multicolumn{2}{l}{ Uncoded process variables } \\
\hline $\begin{array}{l}\text { Milk temperature } \\
\left(\mathbf{x}_{\mathbf{1}}\right)\end{array}$ & $\begin{array}{l}\text { Coagulant } \\
\text { quantity }\left(\mathbf{x}_{\mathbf{2}}\right)\end{array}$ & $\begin{array}{l}\text { Milk temperature } \\
(\mathbf{X 1}){ }^{\circ} \mathbf{C}\end{array}$ & $\begin{array}{l}\text { Coagulant } \\
\text { quantity }\left(\mathbf{X}_{\mathbf{2}}\right) \mathbf{~} \mathbf{L}\end{array}$ \\
\hline 0 & 1 & 15 & 55 \\
-1 & 1 & 25 & 55 \\
0 & 1 & 15 & 55 \\
-1 & 1 & 5 & 55 \\
-1 & 1 & 15 & 40 \\
\hline
\end{tabular}

\subsection{Determination of Milk-Clotting Activity (MCA)}

For MCA, $1 \mathrm{~mL}$ of latex or rachis' juice extract was mixed with $10 \mathrm{~mL}$ of low-fat $(1 \mathrm{~g} / 100 \mathrm{~mL})$ pasteurized milk (containing $0.02 \mathrm{~g} / 100 \mathrm{~mL}$ of $\mathrm{CaCl}_{2}$ ) and incubated among 40 and $80^{\circ} \mathrm{C}$. The period elapsed from the time when the coagulant was added and when milk clotting occurred was registered as the clotting time $t(s)$. The clotting time was determined in triplicates at each temperature and the experiment was repeated three times in different days. The MCA was defined in terms of Soxhlet units (US) as the quantity of protein present in $1 \mathrm{~mL}$, needed to coagulate 1 $\mathrm{mL}$ low fat milk in $40 \mathrm{~min}$ (2400 s) at each temperature evaluated.

$$
M C A(U S)=\frac{2400}{t} \times \frac{S}{E}
$$

Were $\mathrm{t}=$ clotting time $(\mathrm{s}) ; \mathrm{S}=$ volume of milk $(\mathrm{mL}) ; \mathrm{E}=$ volume of extract or latex $(\mathrm{mL})$.

\subsection{Manufacture of Waragashi}

Fresh cow milk is lightly heated at SM-8B Water Bath Microfield instrument England and coagulates with latex of ones of coagulant for 10 minutes. The obtained coagulum was straining after 10 other minutes of heat at $100^{\circ} \mathrm{C}$ on the heating plate (CAMAG TLC PLATE HEATER III). The waragashi was left at drainage for one hour before it weighing. Coagulants were added to heated milk according to the experimental design with two factors (temperature, amount of coagulant) generated by Design Expert statistical software (version 6.0, Stat-Ease, Inc., Minneapolis, MN).

\subsection{Physico-chemical Analysis}

Total solids content and acidity was determined according to the methods described by [5]. Cheese samples were analyzed for $\mathrm{pH}$ values by using a digital $\mathrm{pH}$-meter (HANNA HI 98129). The fat was extracted from cheese in a soxhlet extractor with petroleum ether. The fat content was gravimetrically measured after the removal of the solvent by the rotary evaporation under a vacuum. The total ash is determined by gravimetry according to standard [5]. Color varieties of different types of waragashi was measured using a colorimeter CR400 (KONICA MINOLTA SENSING, INC) in the trichromatic system $\left(\mathrm{L}^{*}, \mathrm{a}^{*}\right.$ and $\left.\mathrm{b}^{*}\right)$ in accordance with standards of the International Committee. The maximum shear force was measured using a texturometer brand LF plus (LLOYD instruments, AMETEK Compagny) equipped with a probe of triangular Warner Bratzler shear type. The elongation speed of the machine was applied to $62 \mathrm{~mm} / \mathrm{min}$. 
The maximum strength was expressed in Newton. For samples of fresh cheese, the dimensions are used $(3 \times 2.5 \times$ $2.5 \mathrm{~cm}$ ) (length $\times$ width $\times$ height). The central part of Waragashi was cut into cubes $\left(1 \mathrm{~cm}^{3}\right)$ with an ultrathin stainless sheet before evaluation. All physico-chemical analysis tests were conducted in triplicate.

$$
Y_{K}=a_{k 0}+\sum_{i=1}^{n} a_{k i} X_{i}+\sum_{i=1}^{n} a_{k i i} X_{i}^{2}+\sum_{i=1}^{n-1} \sum_{j=i+1}^{n} a_{k i j} X_{i} X_{j}+e_{k}
$$

where $Y_{k}$ is the response variable $\left(Y_{1}, Y_{2}, Y_{3}\right.$ and $Y_{4}$ were the yields of waragashi respectively based on C. procera, $P$. alba, $C$. papaya and $A$. comosus), $\mathrm{x}_{\mathrm{i}}$ 's represent the coded independent variables ( $\mathrm{x}_{1}=$ Milk temperature and $\mathrm{x}_{2}=$ Coagulant quantity); and $a_{k 0}$ is the value of fitted response at the center point of design, i.e., point $(0,0,0), \mathrm{a}_{\mathrm{ki}}, \mathrm{a}_{\mathrm{kii}}$ and $\mathrm{a}_{\mathrm{kij}}$ were the linear, quadratic and cross-product regression coefficients, respectively. The signs of these coefficients are used to highlight the synergy (+sign) and the antagonist (-sign) variables controls.

The results were statistically processed by analysis of variance to assess the influence of the control variables on the responses observed. Tests and multiple regression curve

\subsection{Statistical Analysis and Optimization}

The second-order polynomial equation was fitted to the experimental data of each dependent variable as given below:

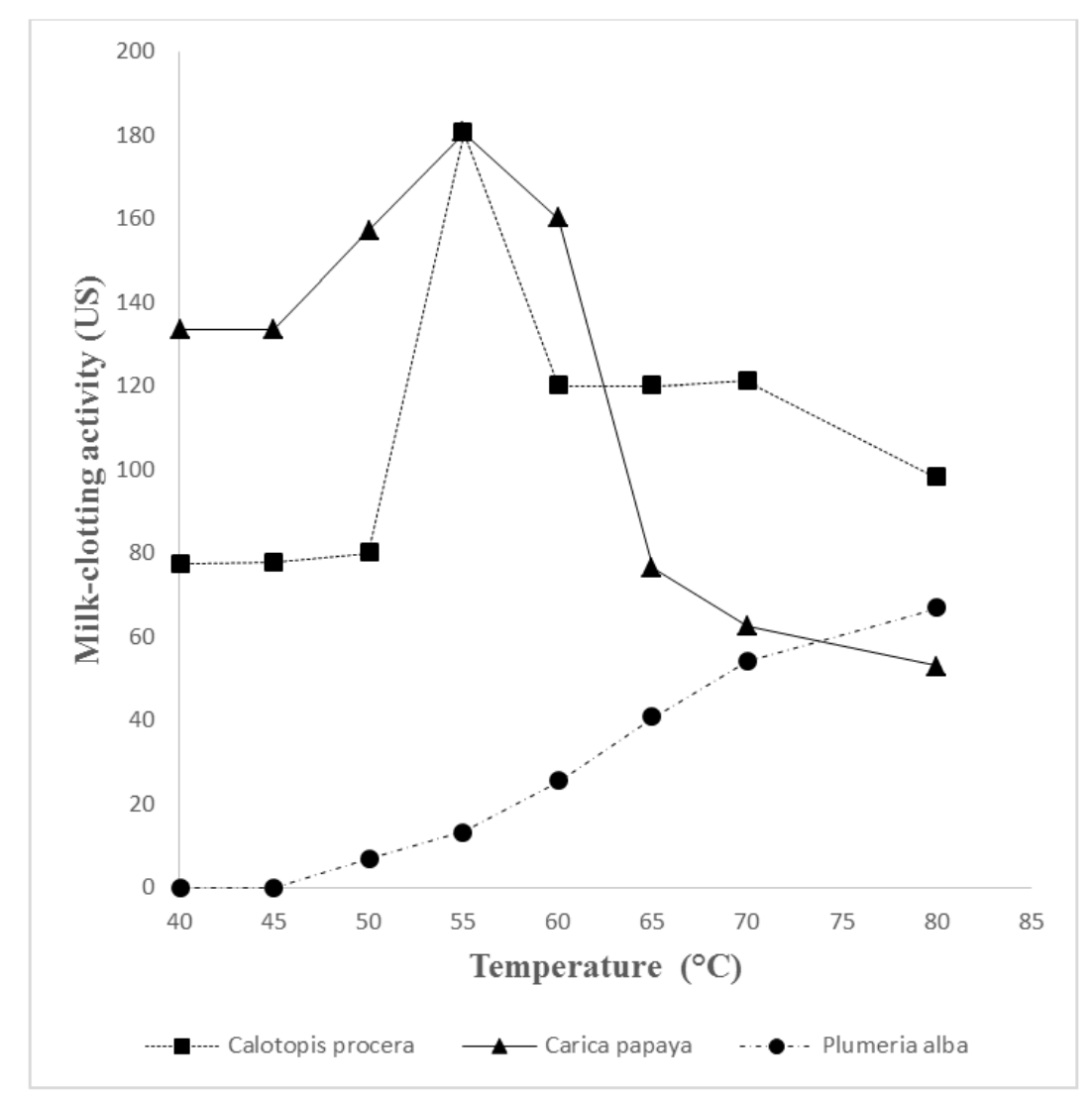

Figure 1. Temperature effect on the milk-clotting activity (MCA) of Calotopis procera, Plumeria alba and Carica papaya latex.

The MCA relative percentage $(\%)$ represents the mean of three independent determinations performed in triplicate for each fresh plant extract. The maximum MCA (100\%) was determined for each plant extract. Bars represent standard deviations. The latices of $C$. procera and $C$. papaya exhibited a maximum $\mathrm{MCA}$ at temperatures close to $55^{\circ} \mathrm{C}$, whereas the plot of response surfaces were used to develop mathematical models to simulate the experimental phenomenon. The software Statgraphics Plus 3.0 (Statgraphics, 1997) and Statistica (StatSoft, 1995) were used for this purpose.

\section{Results and Discussion}

\subsection{Milk-clotting Properties of Plant Extracts}

The effect of temperature on the milk-clotting activity (MCA) of P. alba, C. papaya, and C. procera latices are shown in Figure 1. 
found between the three plant extracts, which can be attributed to the differences in their enzymatic activity and protease content. The types of proteases (e.g., cysteine, serine, and aspartic) and their specificity are of great relevance and define their use in food processing. However, at high temperatures, the coagulation process slows down [8]. MCA is also dependent on the concentration of enzymes, and the milkclotting time decreases with increasing enzyme concentration [9]. This observation is linked to the increase in the k-casein proteolytic activity, although there is no direct proportionality between these values [10] and the yield of Waragashi cheese. Thus, our results were consistent with the model proposed by van Hooydonk and Walstra [11], which revealed clotting time as a function of the reciprocal enzyme concentration.

\subsection{Cheese (Waragashi) Curd Yield}

Plant coagulants are an effective substitute for chymosin in the cheese-making process. For example, C. procera has been used for a long time by the Peulh community (West Africa) for Waragashi cheese production. Meanwhile, the potential of plant coagulants for such applications depend on their catalytic properties, stability, and specificity, as these factors can affect yield and sensory properties of the cheese [12]. Generally, chymosin is considered to exhibit proteolytic specificity well-suited for clotting bovine milk, offering the best yields during the cheese-making process [12, 13]. As shown in Table 2, there were significant differences in curd yield $(\mathrm{p}<0.05)$ between the different types of coagulant.

Table 2. Regression summaries for yield and analysis of variance for production of Waragashi $\left(Y=a_{0}+a_{1} x_{1}+a_{2} x_{2}+a_{3} x_{1}^{2}+a_{4} x_{2}^{2}+a_{5} x_{1} x_{2}\right)$.

\begin{tabular}{llllll}
\hline \multirow{2}{*}{ Coefficients } & Calotopis procera & & Plumeria alba & \multicolumn{2}{c}{ Carica papaya } \\
\cline { 2 - 6 } & CR & P & CR & P & CR \\
\hline $\mathrm{a}_{0}$ & 34.7319 & 0.269 & -94.088 & 0.056 & 44.3108 \\
$\mathrm{a}_{1}$ & -0.4585 & 0.636 & 1.1382 & 0.417 & 0.061 \\
$\mathrm{a}_{2}$ & -0.3307 & 0.766 & 3.1682 & 0.075 & $0.005^{*}$ \\
$\mathrm{a}_{3}$ & -0.0724 & $0.012^{*}$ & -0.0166 & 0.604 & -1.3197 \\
$\mathrm{a}_{4}$ & -0.0004 & 0.965 & -0.0278 & 0.078 & -0.0708 \\
$\mathrm{a}_{5}$ & 0.0341 & $0.024 *$ & 0.0103 & 0.561 & 0.0125 \\
$\mathrm{R}^{2}$ & 0.88 & & 0.86 & $0.015 *$ & -0.019 \\
\hline
\end{tabular}

* = significant at $5 \%$ level of confidence interval.

Cheese yield also depends on factors such as milk quality, milk composition, heat treatment of milk, the type of cheese, and processing method. The simplest procedure to prepare cheese has been previously described by [14]. In the present study, multiple regression analysis was used to develop models that simulate the evolution of the production yield of Waragashi cheese depending on the temperature and amount of the coagulant (Figure $2 \mathrm{~A} \mathrm{C}$ ).
$\mathrm{Y}_{1}($ C. procera $)=34,7319-0,4585 \mathrm{X}_{1}-0,3307 \mathrm{X}_{2}-0,0724 \mathrm{X}_{1}^{2}-0,0004 \mathrm{X}_{2}^{2}+0,0341 \mathrm{X}_{1} \mathrm{X}_{2}$

(A)

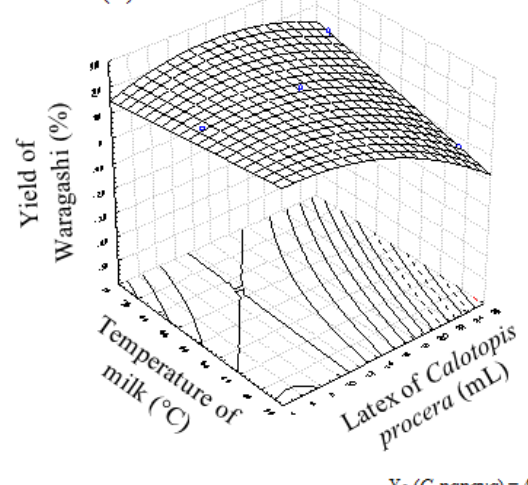

(B)

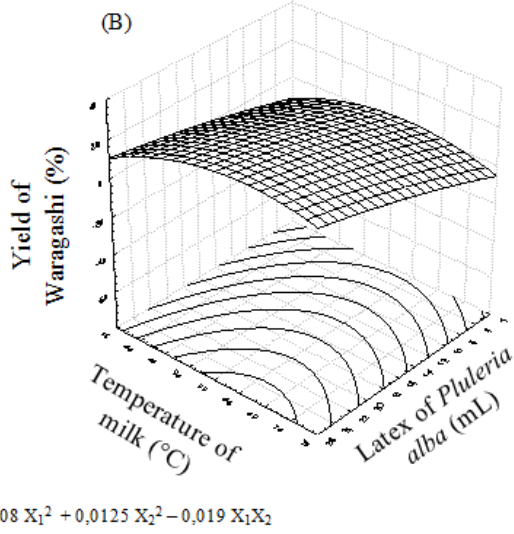

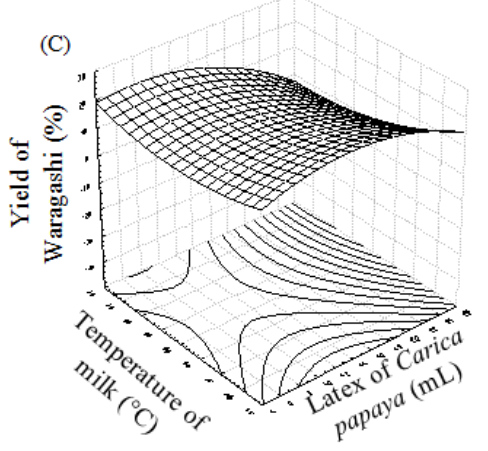

Figure 2. Evolution of Waragashi yield according to the quantity of coagulant and the temperature of milk. 
The developed models demonstrated regression coefficients greater than 0.75 (Table 2), indicating a good fit with the experimental phenomenon [16]. Analysis of Figure 2A showed that the variation of production depended on the variables by $88 \%$ (temperature of milk and quantity of $C$. procera latex). The linear and quadratic terms of the amount of C. procera latex exhibit a significant $(\mathrm{p}<0.05)$ and antagonist influence on the yield of Waragashi. The increase in the amount of $C$. procera latex from 5 to $25 \mathrm{~mL}$ resulted in a gradual decrease in yield. In addition, the increasing milk temperature $\left(40-70^{\circ} \mathrm{C}\right)$ with small amounts of $C$. procera latex $(5-14 \mathrm{~mL})$ did not significantly influence the yield. Furthermore, the interaction between these two parameters (temperature of milk and quantity of $C$. procera latex) had a significant and synergistic influence on the yield of Waragashi cheese. The highest yield for this coagulum was obtained below $60^{\circ} \mathrm{C}$ with less than $12 \mathrm{~mL}$ of $C$. procera.

The temperature of the milk and amount of $P$. alba latex affected the yield of Waragashi cheese by $86 \%$ (Figure 2B). The linear terms of the temperature and amount of $P$ alba latex positively affected the yield, while the quadratic terms exhibited a negative influence. However, these effects were not statistically significant $(\mathrm{p}>0.05)$. The increase in the amount of $P$. alba latex from 5 to $25 \mathrm{~mL}$, followed by a concomitant increase in temperature from 40 to $70^{\circ} \mathrm{C}$, led to an increase in production efficiency, thereby highlighting the positive interaction between these two parameters (temperature of milk and amount of $P$. alba latex) on the yield.

The change in the yield of Waragashi cheese were $92 \%$ and $95 \%$ dependent on the temperature of the milk and quantity of the latex of $C$. papaya (Figure 2C), respectively. The linear term of temperature in the regression equation for the $C$. papaya latex exhibited a significant influence $(p<0.05)$, but synergistic effect on the yield of Waragashi cheese. Similarly, the quadratic term of the temperature of each of these equations exhibited a significant influence $(p<0.05)$, but antagonistic effect on the yield of Waragashi cheese. However, the linear term of amount for $C$. papaya latex negatively influenced the performance. Furthermore, the interaction between the two parameters (temperature of milk and amount of $C$. papaya latex) exhibited an antagonistic effect on the yield.

\subsection{Physicochemical Characteristics of Waragashi Cheese}

Table 3 shows the physicochemical characteristics of the Waragashi cheese produced with different latices.

Table 3. Physico-chemical characteristics of waragashi produced with different latex.

\begin{tabular}{|c|c|c|c|c|c|c|c|}
\hline Waragashi & Dry matter (\%) & $\operatorname{Ash}(\%)$ d. b & Fat $(\%)$ d. b & Protein (\%) d. b & Total sugar $(\%) * d . b$ & Total acidity (\%) d. b & pH \\
\hline Calotopis procera latex & $37.46 \pm 0.90 \mathrm{a}$ & $5.22 \pm 0.01 \mathrm{a}$ & $19.67 \pm 0.20 \mathrm{a}$ & $23.11 \pm 0.21 \mathrm{a}$ & $14.54 \pm 0.25 \mathrm{a}$ & $0.12 \pm 0.04 \mathrm{a}$ & $6.14 \pm 0.03 a$ \\
\hline Carica papaya latex & $35.35 \pm 0.12 b$ & $5.79 \pm 0.14 \mathrm{a}$ & $21.73 \pm 0.19 \mathrm{a}$ & $19.36 \pm 0.17 b$ & $17.77 \pm 0.31 b$ & $0.05 \pm 0.01 \mathrm{~b}$ & $6.68 \pm 0.04 b$ \\
\hline Plumeria alba latex & $32.91 \pm 0.89 \mathrm{c}$ & $6.64 \pm 0.04 b$ & $12.97 \pm 0.15 b$ & $24.21 \pm 0.13 \mathrm{a}$ & $23.26 \pm 0.20 \mathrm{c}$ & $0.10 \pm 0.12 b$ & $6.30 \pm 0.01 \mathrm{c}$ \\
\hline
\end{tabular}

Table 4. Texture and color profile of waragashi produced with different latex

\begin{tabular}{llll}
\hline \multirow{2}{*}{ Waragashi } & Color & & \\
\cline { 2 - 4 } & $\mathbf{L}^{*}$ & $\mathbf{A}^{*}$ & \multicolumn{2}{c}{ Texture (N) } \\
\hline Calotopis procera latex & $74.87 \pm 0.08 \mathrm{a}$ & $-1.94 \pm 0.02 \mathrm{a}$ & $21.11 \pm 0.11 \mathrm{a}$ \\
Carica papaya latex & $94.47 \pm 1.25 \mathrm{~b}$ & $-2.55 \pm 0.02 \mathrm{~b}$ & $1.89 \pm 0.97 \mathrm{a}$ \\
Plumeria alba latex & $94.26 \pm 0.22 \mathrm{~b}$ & $-2.50 \pm 0.03 \mathrm{~b}$ & $2.65 \pm 1.51 \mathrm{a}$ \\
\hline
\end{tabular}

The mean values followed by same letter in the same column are not significantly different $(\mathrm{p}<0.05)$.

* = by difference

$\mathrm{L}^{*}=$ brightness; $\mathrm{A}^{*}=$ red indicator; $\mathrm{B}^{*}=$ yellow indicator

Dry matter, ash, fat, protein, total acidity content, and $\mathrm{pH}$ were determined for the Waragashi cheese, while total sugar was determined by differences on each Waragashi. The dry matter obtained was $37.46 \%, 35.35 \%$, and $32.91 \%$ for the Waragashi cheese prepared from the lattices of $C$. procera, $C$ papaya, and $P$. alba, respectively. No statistically significant result $(\mathrm{p}>0.05)$ of the Waragashi cheese prepared from the lattices of $C$. papaya and $P$. alba was obtained. The protein content varied for each Waragashi cheese, ranging from 19.36 to $24.21 \%$. The highest value was obtained for the Waragashi cheeses made from $P$. alba. This result was statistically different for those prepared with $C$. papaya latex, but not different for the one prepared with $C$. procera latex. Similarly, the protein, ash, fat, and total sugar content varied as a function of the different coagulants. Meanwhile, the dry matter, $\mathrm{pH}$, total acidity, and sugar and ash content of the
Waragashi cheese were similar to those reported by Mazou et al. [14].

\subsection{Waragashi Cheese Texture and Color Profile Analysis}

The results of the texture and color profile analysis of Waragashi cheese produced from the different latices are shown in Table 4. The hardness of the Waragashi cheese varied as a function of the different coagulants, ranging from 1.34 to $2.65 \mathrm{~N}$. The highest value was obtained for the Waragashi cheese prepared with $C$. papaya latex, while those prepared with $C$. procera and $P$. alba latices showed the lowest value (1.89 and $1.34 \mathrm{~N}$, respectively). However, all of these values were not significantly different $(\mathrm{p}>0.05)$. These results were in accordance with those of the dry matter for each Waragashi cheese. Fresh curds usually present low hardness, which is related to their high moisture content (55-65\%) and loose 
structure $[6,15]$ It has been reported that fresh curd (3-h old) showed hardness values as low as $1.3 \mathrm{~N}$ [17].

The brightness $\left(\mathrm{L}^{*}\right)$, red indicator $\left(\mathrm{a}^{*}\right)$, and yellow indicator $\left(b^{*}\right)$ of each Waragashi cheese were also investigated (Table 4). As shown, all of the Waragashi cheeses were white and light. The brightness varied between 74.87 and 94.47. The highest value was obtained for the Waragashi cheese prepared with $C$. papaya latex, which indicated that it was lighter than the others. However, the brightness of the Waragashi cheese prepared with $P$. alba latex was not significantly different $(\mathrm{p}>0.05)$ from that prepared with $C$. papaya latex. All Waragashi cheeses exhibited negative values for the red indicator, which indicated that the Waragashi cheese produced was not red but tended to be yellow.

\section{Conclusion}

The results of these experiments clearly indicate that, similar to the latices of $C$. procera and C. papaya, the $P$. alba latex can be used to produce Waragashi cheese. However, due to the diversity of the physicochemical characteristics of Waragashi cheese produced from different coagulants, a comparative study of the cheese microscopic structures should be carried out to appreciate the modifications that were made. Similarly, the identification of $P$. alba latex proteins responsible for milk coagulation should be considered.

\section{Conflicts of Interest}

The authors declare no conflicts of interest.

\section{References}

[1] Farid, B, Lamine, B, Hyacinthe, A, Innocent, B, Bénédicte, C, Fatiou, T. and Ambaliou S. (2007). Propriétés coagulantes de Calotropis procera et ses possibilités d'utilisation en industrie agro-alimentaire. Revue CAMES Série A, 5; 7-12.

[2] Adetunji, V. O. and Salawu, O. T. (2008). West African soft cheese 'wara' processed with Calotropis procera and Carica papaya; A comparative assessment of nutritional values. African Journal of Biotechnology 7 (18); 3360-3362.

[3] Roseiro, L. B, Barbosa, M, Ames, J. and Wilbey, A. (2003). Cheesemaking with vegetable coagulants-theuse of Cynara L. for the production of ovine milk cheese. International Journal of Dairy Technology 56; 76-85.

[4] Emmanuelle C. (2008). Plantes laticifères; Mise en évidence et applications des activités lipasiques de Carica pentagona et Plumeria rubra. Universite montpellier II sciences et techniques du languedoc. École Doctorale; Sciences des procédés-Sciences des aliments, $154 \mathrm{pp}$.

[5] AOAC. (1990). Official Methods of Analysis.15th edition. Association of Official Analytical Chemists, Gaithersburg, MD.

[6] Miguel, A. M, Teresa, C. P, María, E. L, Juan, C. R, María, J. T, Aarón, F. G. and Belinda, V. (2013). Comparison of the milk-clotting properties of three plant extracts. Food Chemistry 141; 1902-1907.

[7] Silvestre, M, Carreira, R, Silva, M, Corgosinho, F, Monteiro, M. and Morais, H. (2012). Effect of $\mathrm{pH}$ and temperature on theactivity of enzymatic extracts from pineapple peel. Food and Bioprocess Technology. 5; 1824-1831.

[8] Soledad, C, Lara, S, Dorotea, L. and Jose, N. R. (2007). Characterization of the milk-clotting properties of extracts from artichoke (Cynara scolymus, L.) flowers. International Dairy Journal 17; 1393-1400.

[9] Chitipinityol, S. and Crabbe, M. J. C. (1998). Chymosin and aspartic proteinases. Food Chemistry 61; 395-418.

[10] Lopez, M. B, Lomholt, S. B, Qvist, K. B. (1998). Rheological properties and cutting time of rennet gels. Effect of $\mathrm{pH}$ and enzyme concentration. International Dairy Journal 8; 289293.

[11] van Hooydonk, A. C. M. and Walstra, P. (1987). Interpretation of the kinetics of the renneting reaction in milk. Netherlands Milk Dairy Journal 41; 19-47.

[12] Jacob, M, Jaros, D. and Rohm, H. (2011). Recent advances in milk clotting enzymes. International Journal of Dairy Technology 64; 14-33.

[13] Vallejo, J, Ageitos, J, Poza, M. and Villa, T. (2012). Short communication; A comparative analysis of recombinant chymosins. Journal of Dairy Science 95; 609-613.

[14] Mazou, M, Tchobo, F. P, Degnon, G, Mensah, A. and Soumanou, M. (2012). Effect of temperature and salt on the quality of waragashi cheese during storage in Benin Republic. African Journal of Food Science 2; 494-499.

[15] Tunick, M. and Van Hekken, D. (2010). Rheology and texture of commercial queso fresco cheeses made from raw and pasteurized milk. Journal of Food Quality 33; 204-215.

[16] Henika, R. G. (1982). Use of the surface response methodology in sensory evaluation. Food Technol. 36; 96102.

[17] Katsaros, G. I, Tavantzis, G. and Taoukis, P. S. (2010). Production of novel dairy products using actinidin and high pressure as enzyme activity regulator. Innovative Food Science and Emerging Technologies 11; 47-51. 